\title{
Health Care Provider Postal Address
}

National Cancer Institute

\section{Source}

National Cancer Institute. Health Care Provider Postal Address. NCI Thesaurus. Code C93844.

A contact point used to send physical forms of communication to the healthcare provider. 